\title{
Société Luxembourgeoise de Biologie Clinique (SLBC) - International Scientific Award
}

The Roche-Prophac award will be decreed for the first time by the Luxembourg Association of Clinical Biology (SLBC) at the 27th National Day of Clinical Biology (Journée Nationale de Biologie Clinique, JNBC) in September 2007.

This prize of $€ 7500$ intends to reward research work in the field of laboratory medicine.

\section{Conditions of participation}

The candidates must not be aged more than 40 years in the year of the deposit of their file and must currently exert an activity in a university laboratory, hospital or private clinical biology laboratory in Luxembourg or abroad.

Scientific work which will be eligible for a candidature will have to cover a certain field or subject and should represent a major progress in clinical biology or medical microbiology.

The date of publication of the scientific work which is submitted for the Roche-Prophac prize should not be prior to 1 st January 2005. The manuscripts submitted by the candidate must be published or accepted for publication in international scientific journals which are indexed in Medline.

The prize winner commits himself to presenting in a plenary session at the JNBC conference on the subject of his work.

The jury can suspend the prize, if no eligible candidatures are submitted. The amount or part of the amount of the prize can be made available exceptionally at the National Day of Clinical Biology of the following year if several candidatures would be retained by the jury.
The jury has the following composition:

- President, vice-president and secretary of the SLBC.

- The editor-in-chief of the Bulletin of the SLBC.

- A committee of experts named by the board of the SLBC.

The candidate's file must comprise the following elements:

- Heading and a brief summary of the research work in three specimens.

- Reprints of scientific publications related to the research work that is submitted for the Roche-Prophac award in three specimens.

- A curriculum vitae and a current list of publications in three specimens.

- The candidature for the Roche-Prophac award excludes any candidature for another prize with the same research work. A written declaration signed by the candidate that the work subjected to the candidature for the Roche-Prophac award was, or is not submitted, or has been awarded with another scientific prize must be included.

- The dossiers can be submitted in French, German or English.

- The candidate's file will have to be sent at the latest by 30th May 2007 to the following address:

\section{Société Luxembourgeoise de Biologie Clinique}

\section{B.P.: 2187}

\section{L-1021 Luxembourg}

Alternatively by electronic mail to the following address: matthias.opp@Ins.etat.lu 